\title{
Publication Activity among Academic Librarians
}

\begin{abstract}
A study of the publication output of librarians at ten large university libraries was undertaken in order to suggest norms of productivity for the profession. Publications lists were obtained for the sample libraries along with biographical data for publishing librarians. Relationships between productivity and age, professional maturity, educational background, and position held were investigated. Favored publication outlets also were examined, and measures were taken of both individual and staff productivity. The data thus obtained are related to administrative policies concerning evaluative criteria for librarians, tenure eligibility periods, and apportionment of staff time.
\end{abstract}

D URING THE PRESENT PERIOD of economic retrenchment in higher education, the operations of academic libraries and the contributions of librarians to the educational enterprise are being scrutinized carefully by parent institutions. Acquisitions and personnel budgets are declining, and librarians are likely to be measured against higher standards of performance now than they were in the expansive decade of the sixties. It is particularly important, therefore, that clear and reasonable criteria are available for the evaluation of librarians in all the areas of accomplishment traditionally regarded as indexes of academic excellence. Research and publication activity is certainly one of

Paula De Simone Watson is assistant reference librarian, University of Illinois Library, Urbana. The author acknowledges the help of the many librarians who responded to her requests for information, especially James $F$. Govan, University of North Carolina at Chapel Hill; Richard W. Boss, Princeton University; and James Davis, University of California, Los Angeles. She also thanks Charlene Renner, University of Illinois, for her helpful comments. the most important of such indexes. It is the purpose of this paper to provide some norms of publishing productivity for librarians. The approach is purely quantitative; no attempt is made to address the question of qualitative standards.

The publishing output of a sample of university librarians is surveyed over a five-year period. Relationships between productivity and age, professional maturity, educational background, and position held are examined. Particular attention is given to the contribution of young professionals who, at institutions where faculty status has been secured, are now likely to face more stringent tenure criteria than have their older colleagues in the past. Estimates of the proportion of actively publishing librarians in the total population also are obtained, and an effort is made to categorize librarians' publications.

\section{Methodology}

The original intention of the study was to survey the publication output of librarians at the very largest academic libraries on the assumption that such in- 
stitutions would have high evaluative criteria for teaching faculty and that these criteria might influence the standards set for librarians. Librarians at such schools presumably also have the most bountiful research resources at their disposal and work daily in an atmosphere in which publication is highly valued as an indicator of worth. Their research output might, therefore, be used as a norm against which to measure others in the profession.

Lists of publications of librarians at as many of the fifteen largest members of the Association of Research Libraries as possible were gathered from published sources. University bibliographies of faculty publications and library directors' annual reports listing staff publications were consulted. In one case, a list was compiled from an in-house publication which announces librarians' research and professional accomplishments as a regular feature. Letters requesting unpublished lists of publications were sent to directors of libraries for which published lists were unavailable. The response to these requests, with a few notable exceptions, was poor. Many libraries apparently do not maintain composite publication lists for the staff as a whole, but simply record individual accomplishments in personnel folders.

The sample was, consequently, expanded to include slightly smaller ARL libraries for which published data were available. The final group consists of ten public and private academic research libraries. Librarians at four of these have faculty status. At one institution they have had academic status since 1972. The period surveyed for most librarians was the five years beginning with the academic year 1969-70 (or the calendar year 1970, if calendar years were the unit of record) and ending with the academic year 1973-74, or the calendar year 1974. No attempt was made to gather data for later years on the assumption that the lag time for compiling of publication lists by sample institutions would be likely to be one to two years. For one institution, data were gathered which covered the first three years of the survey period, and data for the remaining two years were subsequently found to be unavailable. For this library, data for the two earlier years are included instead.

Organization charts also were obtained wherever possible to establish the publishing librarian's position in the administrative hierarchy. Those who have the title director or its equivalent, assistant or associate director, or division head were classed as administrators.

A second category consisted of department heads and branch librarians, and a third was made up of subject or technical specialists. Included in this group were specialized bibliographers, collection curators, personnel officers, audiovisual specialists, automation personnel, and other technical experts. Almost all the bibliographers so classed have a higher degree in their field of specialization. In a few isolated cases, however, librarians holding no such degree but working as bibliographers in fields traditionally acknowledged as specialists' fields (such as Latin American studies) also were designated as subject specialists.

The last category comprises the large group of librarians who may be described as generalists working in supervised positions. These include, for example, reference librarians, acquisitions librarians, catalogers, and branch library assistants.

Once the publication lists were obtained, biographical information on publishing librarians was gathered. The Biographical Directory of Librarians in the United States and Canada was consulted and supplemented with other relevant biographical sources. Where 
biographical data could not be found by indirect means, librarians were sent a short questionnaire asking them to provide their year of birth, the first year worked as a professional librarian, their earned degrees, and positions held (indicating supervisory responsibility) during the survey period. The response to these questionnaires was gratifying. Biographical information is incomplete for only about 5 percent of the sample population.

\section{Findings}

With this information in hand, various tabulations were made. For each publication the following were noted: (1) the age of the librarian in the year of publication; (2) the number of years the author had been in the profession at that time; (3) the higher degrees earned by the author; (4) the position held by the author at the time of publication. Distributions in all of these categories are presented in the tables which follow. Data from several studies of the characteristics of academic librarians are used in order to compare the distributions of publishing librarians with the distributions of librarians in the profession as a whole.

Schiller ${ }^{1}$ has compiled information on age, years in the profession, and degrees held by academic librarians which are presented for comparison purposes in Tables 1 and 2. Data on years in the profession also are taken from Massman, ${ }^{2}$ from an unpublished salary study by Chapin, ${ }^{3}$ and from a salary survey sponsored by the Council on Library Resources and compiled by Cameron and Heim. ${ }^{4}$ The latter two studies are perhaps the most reliable yardsticks since they are obtained for universities more comparable in size and type to the sample universities. Cameron and Heim distributions also are presented in Table 2 for positions held by academic librarians. ${ }^{5}$

\section{Age of the Librarian}

Using Schiller's distribution as a measure, it can be seen that age is not a strong determinant of publication productivity (see Table 1). Young librarians between the ages of twenty-five and twenty-nine do seem to publish in lower proportion to their numbers (i.e., they produce 7 percent of the contributions at sample universities, while it is likely that they make up something like 12 percent of the staffs of these libraries). The most productive librarians appear to be between the ages of forty and forty-four, and output does not drop off with increasing age.

Librarians at the sample universities who would be sure to be in the tenure eligibility range at institutions where librarians have faculty status (i.e., those between the ages of twenty-five and twenty-nine) are somewhat less likely, then, to have publications to their credit than are their older colleagues. Since so many individuals enter the profession late in life, ${ }^{6}$ librarians without tenure are likely to be in all but the oldest age groups. Productivity in the tenure eligibility years is more easily examined by considering years of professional experience in relation to publication.

\section{Professional Maturity}

Professional maturity is, in fact, a more potent predictor of publication output than age (see Table 2). Estimates of academic librarians having five or fewer years of experience show that a large number of professionals fall in these categories. At Massman's survey schools, $\mathbf{4 5 . 5}$ percent of the library staffs have five or fewer years of experience. Chapin shows that at least 30 percent are in this group, Schiller finds at least 32.3 percent, and Cameron and Heim place at least 35 percent in this category. ${ }^{7}$ It is quite striking that only 18 percent of all publications in the pres- 
TABLE 1

Age and Degrees Held by Authors of Each Publication at Sample University Libraries

\begin{tabular}{|c|c|c|c|c|c|c|c|c|c|c|c|c|c|c|c|c|}
\hline & \multirow{2}{*}{$\begin{array}{l}\text { Number } \\
\text { of Publi- } \\
\text { cations }\end{array}$} & \multirow{2}{*}{ 25-29 } & \multirow[b]{2}{*}{$30-34$} & \multirow[b]{2}{*}{$35-39$} & \multicolumn{5}{|c|}{ Age (Percentage Distribution) $)^{\circ}$} & \multirow[b]{2}{*}{$\begin{array}{l}65 \text { or } \\
\text { Over }\end{array}$} & \multirow[b]{2}{*}{$\begin{array}{l}\text { Age Not } \\
\text { Known }\end{array}$} & \multicolumn{5}{|c|}{$\begin{array}{l}\text { Degrees Held (Percentage Distribution) } \\
\text { In addition to Library Degree }\end{array}$} \\
\hline & & & & & $40-44$ & $45-49$ & $50-54$ & $55-59$ & $60-64$ & & & $\begin{array}{l}\text { Subject } \\
\text { Masters }\end{array}$ & $\begin{array}{l}\text { Highest } \\
\text { Degree }\end{array}$ & $\begin{array}{l}\text { Uther } \\
\text { Higher } \\
\text { Degrees }\end{array}$ & $\begin{array}{l}\text { No } \\
\text { Lib. } \\
\text { Degree }\end{array}$ & $\begin{array}{c}\text { Not } \\
\text { Known }\end{array}$ \\
\hline $\begin{array}{l}\text { Total Sample } \\
\text { Schiller Distribution }{ }^{\dagger}\end{array}$ & 1,106 & $\begin{array}{c}7 \\
12.2\end{array}$ & $\begin{array}{l}12 \\
12.6\end{array}$ & $\begin{array}{l}11 \\
11.3\end{array}$ & $\begin{array}{l}18 \\
11.8\end{array}$ & $\begin{array}{l}14 \\
12.6\end{array}$ & $\begin{array}{l}13 \\
13.8\end{array}$ & $\begin{array}{c}9 \\
11.3\end{array}$ & $\begin{array}{l}8 \\
8.6\end{array}$ & $\begin{array}{l}3 \\
3.6\end{array}$ & 4 & $\begin{array}{l}27 \\
22.2\end{array}$ & $\stackrel{25}{3.6}$ & 7 & $\begin{array}{l}15 \\
16.5\end{array}$ & 3 \\
\hline
\end{tabular}

- Percentages in distributions in this and other tables may not add exactly to 100 due to rounding.

$\dagger$ Anita R. Schiller, Characteristics of Professional Personnel in College and University Libraries (Urbana, Ill.: University of Illinois Library Research Center, 1968), p.21 and 39

TABLE 2

Years of Professional Experience and Position Held by Authors of Each Publication in Sample University Libraries

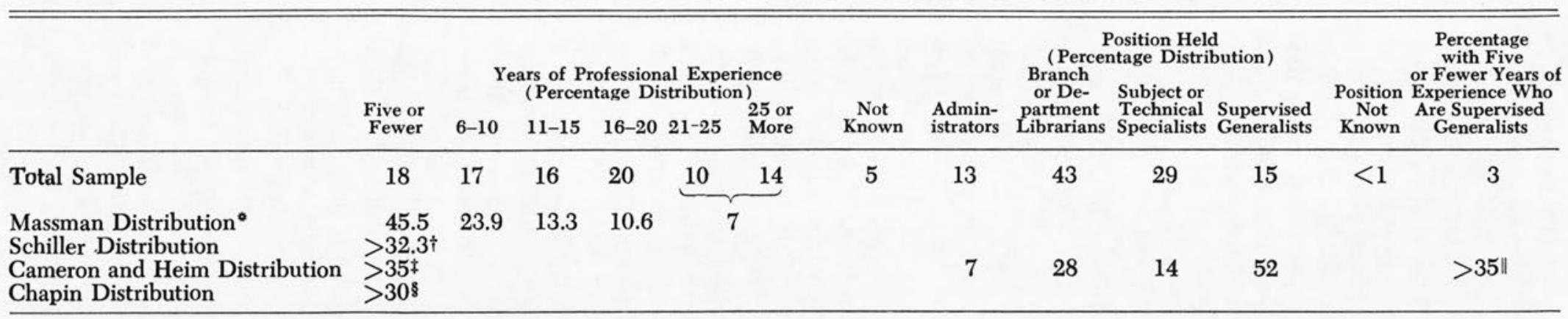

- Virgil F. Massman, Faculty Status for Librarians (Metuchen, N.J.: Scarecrow, 1972), p.116.
$\dagger$ Schiller, Characteristics of Professional Personnel, p.17. This figure is for librarians with "under 5 years of experience." The total number in Schiller's sample for † Schiller, Characteristics of Professional Personnel, p.17. This figure is for

\pm Donald F. Cameron and Peggy Heim, Librarians in Higher Education: Their Compensation Structures for the Academic Year 1972-73 (Washington, D.C.: Council on Library Resources, 1974), p.6. This figure is for "other professionals" (i.e., other than library directors, associate and assistant directors, curator-specialists, and departon Library Resources, 1974), p.6. This figure is for "other professionals" (i.e., other than library directors, associate and assistant directors, curator-specialists, and depart-
ment or branch heads) with less than five years of experience. The total number in Cameron and Heim's sample with five or fewer years of experience, regardless of ment or branch heads) with less than five years of experience. The total number in Cameron and Heim's sample with five or fewer years of experience, regardless of position, would be greater than shown here.

\&ichard E. Chapin, Unpublished salary study of Big Ten University Libraries, 1974-75, Table 9.1. This figure is also for "other professionals" with less than five years of experience. "Other professionals" are defined almost as in Cameron and Heim. The total number in Big Ten libraries with five or fewer years of experience

॥ This figure is for "other professionals" with less than five years of experience. If librarians in their fifth year had been included, this number would be larger. 
ent survey were produced by librarians with five or fewer years of experience. At universities with faculty status for librarians, these less productive staff members would be in the tenure evaluation years.

Also interesting is the high rate of productivity of librarians with sixteen or more years of experience. Those with sixteen to twenty years of experience produce 20 percent of all publications even though, using Massman's distribution as an indicator, they make up only about 11 percent of the staffs of these libraries. Those with twenty-one or more years of service are likely to be only 7 percent of the sample, and yet they account for 24 percent of the publications.

\section{Position Held}

In relating publication to place in the administrative hierarchy, it was found that administrators, branch and department heads, and subject and technical specialists produce the majority of the contributions and publish disproportionately in relation to their numbers (see Table 2). Administrators, using Cameron and Heim's figures as a measure, are likely to be only 7 percent of the population, and yet they generate 13 percent of the survey output. Branch and departmental librarians are likely to be 28 percent of the population, but they produce 43 percent of the published work. Subject and technical specialists contribute 29 percent of the survey output, although they may constitute only 14 percent of the staffs of the sample libraries.

Supervised librarians with no subject specialty, by contrast, publish far less than their colleagues and not at all in proportion to their large numbers. Fifty-two percent of the Cameron and Heim population falls into this category. In the present survey only 15 percent of the publishing is done by this group of librarians. A far smaller proportion of the total output is contributed by the supervised generalists who would be in the tenure evaluation years at institutions where librarians have faculty status. Those with five or fewer years of experience contributed only 3 percent of the books and articles published, while, according to Cameron and Heim, they are likely to make up at least 35 percent of the sample library staffs. It would appear, then, that there exists a high correlation between administrative responsibility and subject or technical specialization and publication output among librarians at large university libraries.

\section{Higher Degrees}

The relationship between subject expertise and publication also is underlined by the large numbers of authors who hold higher degrees in addition to or instead of the master's degree in library science (see Table 1). Almost 60 percent of all articles published are by authors who have a subject master's degree, a Ph.D., or another higher degree. As might be expected, those with a Ph.D. degree publish heavily in relation to their numbers. They are, using Schiller's figures as a yardstick, likely to make up 3.6 percent of the survey population; but they are responsible for 25 percent of the published output. Those who hold no library degree publish in proportion to their numbers and produce a significant fraction of the published work attributed to librarians.

\section{Publication by Type}

A breakdown of librarians' publications by type is presented in Table 3 . The aim of this analysis was to determine what are the most popular outlets for academic librarians' publications and to see whether librarians tend to publish most frequently in vehicles with a national audience. In the purely 
quantitative measure of publication productivity, contributions with national impact are likely to be given greater weight than those in more localized publications. It is also true, perhaps, that publication in national media is considered a measure of quality since there is greater competition to publish in such journals and they are likely to have more stringent criteria for acceptance of contributions.

In tabulating librarians' publications over the five-year period, only those designed to reach audiences beyond the campus community were included. Thus, certain traditional forms of librarians' writing were ignored: for example, guides to the collection, bibliographies of non-unique items in the collection, guides to the use of bibliographic tools, and articles in staff bulletins.

Local library journals were considered to include journals of state or regional library associations and bulletins of local chapters of national library associations. Bulletins of specialized chapters of national organizations, such as the Bulletin of the Map and Geography Section of the Special Libraries Association, a frequent outlet for librarians in this study, were classed as national library journals.

Several university libraries publish their own journals, and some of these have high national reputations. Such established journals were distinguished from staff bulletins and are in a separate group designated "university library journals." National subject journals were considered to be journals in fields other than library science which have a national audience. Archivists' journals were included here as well as exclusively bibliographic journals such as the Papers of the Bibliographic Society of America. Since it might be argued that these two types of journals should be 
considered to be library journals, it should be noted that the number of contributions to such journals in the sample is quite small in proportion to the total. Local or regional subject journals included periodicals published, for example, by state historical or genealogical associations and the magazines of ethnic interest organizations. Popular journals were defined as general interest magazines and newspapers.

Books included both those edited and those authored and were not confined to those produced by large trade or university press publishers. The designation "articles in books" was applied to contributions to conference proceedings and to introductions, articles, and chapters in monographs. Monographs published by libraries for distribution beyond the local community were classed as "library publications." Such work published by other university departments was described by the term "occasional papers series."

A separate category was also established for articles appearing in university journals, which may or may not have broad impact. The last group is comprised of those publications falling into none of the other categories, such as Pathfinders, and of articles in journals not readily classified.

As can be seen from Table 3, an analysis of publications by type points again to the correlation between subject specialization and research productivity. Thirty-seven percent of articles by sample university staff members are found to appear in national and local library journals as compared to 26 percent which appear in journals outside the field of library science.

Of the 37 percent in library journals, however, 21 percent are book reviews. The overwhelming majority of these are the short notes in Library Journal, and most are probably reviews of books on subjects other than library science.
If book reviews are discounted, it is evident that the librarians surveyed publish at least as frequently in journals outside the field of library science as they do in journals in the field.

It seems unlikely that librarians without advanced training in a subject field could succeed in contributing regularly to subject journals. Librarians do appear to publish mainly in media which have national impact, except for the reasonably large percentage of articles published in local or regional subject journals. It may be that local or regional library journals tend to be outlets more for public librarians than for academic librarians.

\section{Staff Productivity in Sample University Libraries}

Data are presented in Table 4 which are aimed at demonstrating the magnitude of staff and individual productivity. A relatively small percentage of the staff of each university library publishes in any given year. The range is from an average percentage of 3.6 percent to 11.4 percent, with the average for all staffs at 7.2 percent. During the five-year period surveyed, the average number of publications per publishing librarian ranges from 1.5 to 12.1 , with the average for the whole sample 4.2. Discounting book reviews, the average ranges from 1.4 to 6.0 , with the average number for the entire sample 3.3. That the average is artificially inflated by a small number of anomalously prolific library staff members is indicated by the smaller number found for the median number of publications per staff member in the survey period. This ranges from a high of 3 at University $\mathrm{I}$ to a low of 1 publication in five years at four schools. Again, the medians drop when book reviews are excluded, reaching a high of 2.5 at University $\mathrm{E}$ and falling to 1 at six schools.

The median productivity for the to- 
TABLE 4

Output of Publishing Librarians in Sample University Librakies

\begin{tabular}{lcccccc}
\hline \hline & $\begin{array}{c}\text { Number of } \\
\text { University }\end{array}$ & $\begin{array}{c}\text { Number of } \\
\text { Publishing } \\
\text { Librarians }\end{array}$ & $\begin{array}{c}\text { Median No. } \\
\text { of Publications } \\
\text { During } \\
\text { 5-yr. Period }\end{array}$ & $\begin{array}{c}\text { Number } \\
\text { Used to } \\
\text { Calculate } \\
\text { Median } \dagger\end{array}$ & $\begin{array}{c}\text { Avg. No. } \\
\text { of Publications } \\
\text { During } \\
\text { 5-yr. Period } \ddagger\end{array}$ & $\begin{array}{c}\text { Avg. \% Staff } \\
\text { Publishing in } \\
\text { Any Given Yr. }\end{array}$ \\
\hline University A & 21 & 14 & 1.0 & 11 & 1.5 & 5.4 \\
University B & 136 & 39 & $2.0(1.0)$ & 29 & $3.0(2.3)$ & 8.4 \\
University C & 164 & 49 & $2.0(2.0)$ & 36 & $3.4(2.3)$ & 11.4 \\
University D & 78 & 17 & 1.5 & 11 & $5.5(5.0)$ & 3.6 \\
University E & 71 & 26 & 2.5 & 14 & $3.4(2.3)$ & 9.0 \\
University F & 44 & 19 & 1.0 & 12 & $2.2(2.1)$ & 5.2 \\
University G & 89 & 52 & 1.0 & 32 & 2.1 & 6.8 \\
University H & 256 & 26 & $2.0(1.0)$ & 19 & $12.1(6.0)$ & 8.8 \\
University 1 & 182 & 37 & $3.0(2.0)$ & 23 & $5.6(4.7)$ & 8.0 \\
University J & 65 & 13 & 1.0 & 9 & $3.4(1.4)$ & 4.6 \\
Total Sample & 1,106 & 292 & $2.0(1.0)$ & 196 & $4.2(3.3)$ & 7.2 \\
\hline
\end{tabular}

- The number shown in parentheses is the median number of publications per publishing librarian during the five-year period excluding book reviews.

$\dagger$ Only those librarians known to have been at the institution during the full survey period were included in the calculation of the medians and averages.

$\ddagger$ The number shown in parentheses is the average number of publications per publishing librarian during the five-year period excluding book reviews.

tal survey population is two publications in five years; when book reviews are excluded, it is one. It should be emphasized that these median and average numbers of publications are only for the publishing librarians. For all librarians these would be drastically smaller.

\section{Discussion}

The findings of the present study suggest that some university librarians may have difficulty meeting standards of academic excellence which include publication activity. The compilation of comparative productivity figures for teaching faculty at the sample universities was too large an undertaking for this study. A recent report of survey findings for similar institutions, however, shows that 79 percent of faculty members had published at least one article in the two years surveyed; 28 percent of these had published five or more during the same period. ${ }^{8}$

These drastic differences, both in numbers of staff publishing and in individual productivity between faculty and librarians, indicate that librarians with faculty status are likely to suffer where promotion and tenure decisions concern- ing them are subjected to the same review procedures used to evaluate the teaching faculty. The low productivity found by the present study for professionals with five or fewer years of experience, particularly for those without subject expertise or administrative responsibility, suggests that tenure situations are likely to present severe problems for librarians at such institutions.

Since the relatively small percentage of professionals found to publish here, regardless of education or experience, typically produce only two publications in five years, it may indeed be unreasonable to expect publication for tenure at institutions where librarians have full faculty status. Certainly the first two or three years of professional life, traditionally training years, should be discounted as potentially productive publication years. Young librarians are likely to be too involved in mastering the technical aspects of their jobs to have the time or the perspective necessary to publish. Moreover, if they have no subject specialty, they will have to build an area of expertise in which they can engage in research. 
One means of making it possible for young professionals to meet publication tenure criteria would be, perhaps, to lengthen tenure eligibility periods. Librarians might, for example, begin work without financial penalty in nontenure-track positions and, after two or three years, be placed on the tenure track. Thus postponing the tenure decision would prevent the handicapping of librarians by their necessary apprenticeship years and would enable them to amass the professional or subject expertise required to pursue research.

Perhaps a more workable arrangement for some university libraries would be to designate research as an assigned responsibility of staff members. It is possible that the most productive librarians in this study-administrators, branch librarians, and department heads -have gained their positions of responsibility because they are more competent and more motivated than other professionals. It may also be that their high productivity is due, in part, to the autonomy such librarians have traditional- ly enjoyed in university libraries. Since they can control their work schedules, they can allot time to research that librarians in large departments and under direct supervision cannot.

A recent report from Ohio State University provides an example of how university library work schedules can be organized to facilitate research involvement by all staff members. A few years ago Ohio State University Libraries began allowing librarians who wished to do research to apply for Assigned Research Duty, thus freeing them for a specified time from other tasks in order to pursue a proposed project. Application procedures have now been abandoned, and librarians' jobs are instead defined to include a regular 20 percent time allotment for research and professional development. ${ }^{9}$ A system such as this would have particular benefit for the librarians described in this study as supervised generalists, who were found to have the lowest publication productivity at the sample universities.

\section{REFERENCES}

1. Anita R. Schiller, Characteristics of Professional Personnel in College and University Libraries (Urbana, Ill.: University of Illinois, Library Research Center, 1968), p.17, 21 , and 34. Schiller's sample included one out of five of all those employed in academic libraries in 1966-67, regardless of whether or not they were holders of a master's degree in library science; 46.4 percent were university librarians.

2. Virgil F. Massman, Faculty Status for Librarians (Metuchen, N.J.: Scarecrow, 1972), p.116. Massman's sample consisted of librarians employed in 1969 at nineteen state colleges and universities in Michigan, Minnesota, and Wisconsin. Institutions had an enrollment of 2,000 to 20,000 and were engaged mainly in undergraduate education.

3. Richard E. Chapin, Unpublished salary study of Big Ten University Libraries, 197475 , Table 9.1 .

4. Donald F. Cameron and Peggy Heim, Librarians in Higher Education: Their Com- pensation Structures for the Academic Year 1972-73 (Washington, D.C.: Council on Library Resources, 1974), p.6. The figures cited for the purpose of this study are those for AAUP Committee Z Survey Category I universities (i.e., "universities offering the doctor's degree that conferred in the most recent three years an annual average of fifteen or more earned doctorates covering a minimum of three nonrelated disciplines," p.4).

5. Cameron and Heim, Librarians in Higher Education, p.6.

6. Schiller, Characteristics, p.23. In Schiller's sample nearly half of the academic librarians did not receive their first library degree until they were thirty or more years old.

7. Schiller's 32.3 percent includes all professionals having less than five years of experience. Including those in their fifth year, as we do here, would increase the percentage. Percentages of "other professionals" with less than five years of experience are found by Chapin and by Cameron and Heim. In- 
cluding those in their fifth year as well as those holding administrative, middle management, and subject specialist positions would make the percentage of all professionals with five or fewer years of experience larger than is shown here.

8. Oliver Fulton and Martin Trow, "Research Activity in American Higher Education," Sociology of Education 47:29-73 (Jan. 1974), p.36. These figures are for institutions rated Quality I in the 1969 Carnegie Commission on Higher Education National Survey of Higher Education whose results are reported by Fulton and Trow. Nine of the institutions in the present study are included in this group. Two are rated as Quality II institutions by Fulton and Trow. For Quality II institutions, the percentage of faculty who had published at least one article in the two-year survey period is 72 percent; 20 percent of these had published five or more. In Quality I institutions, 64 percent of faculty members close in age to the least productive group of librarians (i.e., those between the ages of twenty-six and thirty) had published at least one article in the past two years and 13 percent of these had published five or more (p.53). In the nontenured ranks at Quality I universities, 47 percent of the instructors and 80 percent of the assistant professors had published one or more articles during the two-year survey period; 6 percent of the former and 20 percent of the latter had published five or more articles during the same period (p.49).

9. Susan L. Miller and others, "To Be or Not To Be: an Academic Library Research Committee," The Journal of Academic Librarianship 2, no.1:20-24 (March 1976). 